\title{
Stem Cell - Is There Any Role in Tumorigenic Activity
}

\author{
Kök Hücre - Tümörijenik Aktivitede Rolü Var mı?
}

Sonal SAIGAL, Ankur BHARGAVA

Department of Oral and Maxillofacial Pathology, Government Dental College, RAIPUR, INDIA

\begin{abstract}
Stem cells are a quintessential key to proper behavior of homeostatic processes. They are often thought of as the solution to a wide range of human conditions, with the ability to rescue malfunctioning or non-functioning organs and tissues. However, there is increasing evidence that stem cells can play a central role in disease. Most recently stem cells have been implicated in cancer after not responding to homeostasic controls such as proliferation and differentiation. Cancer has long been seen as a disease that arises from mutations that impair the capacity of any cell within the organism to respond to the signals that regulate proliferation. Besides their scarcity or abundance, a second important issue with respect to cancer stem cells is their origin. A new defining model for carcinogenesis, the "cancer stem cell hypothesis" was put forward in 2006, according to which cancer is a stem cell disease that places malignant stem cells at the centre of its tumorigenic activity as they have the capacity to undergo self-renewal, and have the potential to differentiate into different types of cells in a specific lineage.
\end{abstract}

Key Words: Stem cell, Carcinogenesis, Squamous cell carcinoma
ÖZ

Kök hücreler homeostatik süreçlerin anahtarlarıdır. Bir çok durumda, hatalı veya çalışmayan organ ve dokuların yerine konmak üzere çözüm olarak düşünülmektedir. Ancak, kök hücrelerin hastalıklarda da önemli rolü olduğuna dair bulgular artmaktadır. En son hücre çoğalması ve farklılaşması gibi homeostasic kontrollere yanıt vermeyen kanserlerde kök hücreleri suçlanmıştır. Kanser uzun bir süre çoğalmayı düzenleyen sinyallere yanıtı bozan mutasyonlar sonucu gelişen bir hastalık olarak görülmüștür. Kanser kök hücreleri ile ilgili ikinci önemli konu, az veya çok sayıda olmaları ile bağıntısız olarak kökenleridir. Karsinogenez için "kanser kök hücre hipotezi" 2006 yılında tanımlanmıştır. Bu hipoteze göre kanser bir kök hücre hastalığıdır ve malign kök hücreler tümorijenik aktivitenin merkezinde yer alırlar. Bu hücreler kendilerini yenileme ve özgün nesilleri içerisinde değişik hücre türlerine diferansiye olabilme yetisine sahiptirler.

Anahtar Sözcükler: Kök hücre, Karsinogenez, Skuamöz hücreli karsinom

\section{INTRODUCTION}

Stratified squamous epithelia act as a protective interface between the body and the environment. They have a simple organization: proliferation takes place in the basal layer of cells attached to an underlying basement membrane and cells undergo terminal differentiation as they move towards the tissue surface. The outermost cell layers are shed throughout adult life and are replaced through proliferation of a subpopulation of cells in the basal layer known as stem cells (1). In cancers such as squamous cell carcinomas, stem cells may more likely undergo transformation than the proliferating basal layer cells since the latter divide for relatively short periods before terminally differentiating. It is less likely that a large proliferating population could acquire the self renewal potential of stem cells in order to accumulate additional mutations leading to tumorigenesis (2). Nowadays, cancer is increasingly being viewed as a stem cell disease, both in its propagation by a minority of cells with stem-cell-like properties and in its possible derivation from normal tissue stem cells but stem cell activity is tightly controlled, raising the question of how normal regulation might be subverted in carcinogenesis (3). These Cancer Stem Cells (CSCs) are defined as a small subset of cancer cells that constitute a pool of self-sustaining cells with the exclusive ability to maintain the tumor. Currently, there are two hypothetical explanations for the existence of CSCs that state they may arise from normal stem cells by mutation of genes that render the stem cells cancerous or they may come from differentiated tumor cells that experience further genetic alterations and, therefore, become dedifferentiated and acquire CSC-like features (4). 


\section{Types and Properties of Stem Cells}

Stem cells have been classified based on their developmental potential (Table I) (3-7). However the two main categories of stem cells are embryonic and adult stem cells, defined by their source (Table II) $(6,7)$. The types of differentiation in stem cells are shown in Table III (8).

\section{Other Properties}

Self-renewal: They can divide without differentiation and create everlasting supply.

Plasticity: MSCs have plasticity and can undergo differentiation. The trigger for plasticity is stress or tissue injury which upregulates the stem cells and releases chemoattractants and growth factors $(6,8)$.

\section{CSCs could support metastasis}

The process of metastasis consists of a series of linked, sequential steps that must be completed by tumor cells if a metastasis is to develop. Although some of the steps in this process contain stochastic elements, metastasis as a whole favors the survival and growth of a few subpopulations of tumor cells that pre-exist within the heterogeneous parent neoplasm. Metastases can have a clonal origin, and different metastases can originate from the proliferation of single cells. The outcome of metastasis depends on the interaction of metastatic cells with different organ environments (9). There are three main characteristics that define CSCs: differentiation, which provides the ability to give rise to a heterogeneous progeny, self-renewal capability that maintains an intact stem cell pool for expansion, and homeostatic control that ensures an appropriate regulation between differentiation and self renewal according to the environmental stimuli and genetic constraints of each organ tissue, which accounts for the tissue specificity of CSCs (10).
Cancer metastasis requires seeding and successful colonization of specialized CSCs at distant organs. The biology of normal stem cells and CSCs share remarkable similarities and may have important implications when applied to the study of cancer metastasis. Furthermore, overlapping sets of molecules and pathways have recently been identified to regulate both stem cell migration and cancer metastasis (11).

\section{Insights of the differentiation signals for tumorigenesis}

Understanding what controls the maintenance of stem cells and differentiation signals may give insights into the cellular signals involved in cancer, and may ultimately lead to new approaches to differentiation therapy. The signal that controls which daughter cell of an adult stem cell remains a stem cell and which begins the process of determination may be mediated through a number of signaling pathways including the Oct-4, Wnt/-catenin, Notch, Bone Morphogenic Protein (BMP), Janus family kinase, or sonic hedgehog signaling pathways, etc. (Table IV) (12-15).

Cancer has long been seen as a disease that arises from mutations that impair the capacity of any cell within the organism to respond to the signals that regulate proliferation. Besides their scarcity or abundance, a second important issue with respect to CSCs is their origin. The cells of most adult organs can be grouped in three classes: stem cells, Transit Amplifying Cells (TACs) and differentiated cells. Stem cells are capable of forming all the cell types that compose the mature organ. They divide throughout the life of the organism to replace dying cells and maintain tissue homeostasis. In many instances, the division of a stem cell gives rise to one new stem cell and one TAC. TACs undergo a limited number of cell divisions before giving rise to the differentiated cells that ensure organ function. One

Table I: Classification of stem cells based on developmental potential with its properties and examples

\begin{tabular}{|l|c|c|c|}
\hline $\begin{array}{l}\text { Developmental } \\
\text { potential }\end{array}$ & \multicolumn{1}{c|}{ Properties } & Examples & Reference \\
\hline Totipotent & $\begin{array}{c}\text { Able to give rise to all embryonic and } \\
\text { extra-embryonic cell types. }\end{array}$ & Fertilised oocyte or zygote. & 5 \\
\hline Pluripotent & $\begin{array}{c}\text { Give rise to all cell types of the embryo } \\
\text { proper. }\end{array}$ & Embryonic stem cells. & 3,4 \\
\hline Multipotent & Give rise to a subset of cell lineages. & Adult, somatic, or tissue-based stem cells. & 3,4 \\
\hline Oligopotent & $\begin{array}{c}\text { Give rise to a more restricted subset of cell } \\
\text { lineages than multipotent stem cells. }\end{array}$ & $\begin{array}{c}\text { Distributed throughout the mammalian } \\
\text { ocular surface. }\end{array}$ & 3,5 \\
\hline Unipotent & Contribute only one mature cell type. & Type II pneumocyte. & 3,4 \\
\hline
\end{tabular}


Table II: Types of stem cells with their sources of origin

\begin{tabular}{|c|c|c|}
\hline Categories & Source & Reference \\
\hline $\begin{array}{l}\text { Embryonic stem } \\
\text { cells (ESCs) }\end{array}$ & $\begin{array}{l}\text { ESCs are derived from the cells of the inner cell mass of the blastocyst during } \\
\text { embryonic development. They have the capacity to differentiate into any cell type } \\
\text { and the ability to self-replicate for numerous generations. Disadvantage: able to } \\
\text { differentiate into any cell lineage and to proliferate endlessly unless controlled. } \\
\text { Example: teratoma. }\end{array}$ & 6 \\
\hline Adult stem cells & $\begin{array}{l}\text { They can also be autologous and isolated from the patient being treated, whereas } \\
\text { embryonic stem cells cannot. Sources include the umbilical cord, amniotic fluid, } \\
\text { bone marrow, adipose tissue, brain and teeth. }\end{array}$ & 6 \\
\hline $\begin{array}{l}\text { Induced pluripotent } \\
\text { stem cells (iPS) }\end{array}$ & $\begin{array}{l}\text { They are adult or somatic stem cells that have been coaxed to behave like } \\
\text { embryonic stem cells; they have the capacity to generate a large quantity of stem } \\
\text { cells as an autologous source that can be used to regenerate patient specific tissues. }\end{array}$ & 6,7 \\
\hline $\begin{array}{l}\text { Amniotic fluid- } \\
\text { derived stem cells } \\
\text { (AFSCs) }\end{array}$ & $\begin{array}{l}\text { AFSCs can be isolated from aspirates of amniocentesis during genetic screening. } \\
\text { They have the capacity for remarkable proliferation and differentiation into } \\
\text { multiple lineages such as chondrocytes (for cartilage), adipocytes (for fat), } \\
\text { osteoblasts (for bone), myocytes (for muscle), endothelial cells, neuron-like cells } \\
\text { and live cells. }\end{array}$ & 6 \\
\hline $\begin{array}{l}\text { Umbilical cord blood } \\
\text { stem cells (UCBSCs) }\end{array}$ & $\begin{array}{l}\text { UCBSCs derive from the blood of the umbilical cord. They have capacity for self- } \\
\text { replication and multilineage differentiation, and UCBSCs have been differentiated } \\
\text { into several cell types that resemble cells of the liver, skeletal muscle, neural tissue, } \\
\text { pancreatic cells, immune cells and mesenchymal stem cells. Disadvantage: there is } \\
\text { only one opportunity to harvest them from the umbilical cord at the time of birth. }\end{array}$ & 6 \\
\hline $\begin{array}{l}\text { Bone marrow- } \\
\text { derived stem cells } \\
\text { (BMSCs) }\end{array}$ & $\begin{array}{l}\text { BMSCs consist of both hematopoietic stem cells that generate all types of blood } \\
\text { cells and stromal cells (mesenchymal stem cells) that generate bone, cartilage, } \\
\text { other connective tissues and fat. }\end{array}$ & 6 \\
\hline $\begin{array}{l}\text { Adipose-derived } \\
\text { stem cells (ASCs) }\end{array}$ & $\begin{array}{l}\text { ASCs are typically isolated from lipectomy or liposuction aspirates. They have } \\
\text { been differentiated into adipocytes, chondrocytes, myocytes, and neuronal and } \\
\text { osteoblast lineages, and may provide hematopoietic support. } \\
\text { Advantage: adipose tissue is plentiful in many individuals, accessible and } \\
\text { replenishable, the ability to reconstitute tissues and organs using ASCs versus other } \\
\text { adult stem cells has yet to be comprehensively compared and documented. }\end{array}$ & 6 \\
\hline $\begin{array}{l}\text { Mesenchymal stem } \\
\text { cells (MSCs) }\end{array}$ & $\begin{array}{l}\text { MSCs have several important properties: adherence to cell culture polystyrene, } \\
\text { self-replication to multiple passages and differentiation into multiple cell lineages. } \\
\text { They natively form connective tissue, including bone, cartilage, adipose tissue, } \\
\text { tendon and muscle, and participate in the formation of many craniofacial } \\
\text { structures. They can differentiate into multiple cell lineages, including but not } \\
\text { limited to chondrocytes, osteoblasts, myoblasts and adipocytes. They can be } \\
\text { used autologously without concern for immunorejection, have also been used } \\
\text { allogeneically and been shown to heal large defects. }\end{array}$ & 7 \\
\hline $\begin{array}{l}\text { Dental stem cells } \\
\text { (DSCs) }\end{array}$ & $\begin{array}{l}\text { DSCs can be obtained from the pulp of the primary and permanent teeth, from } \\
\text { the periodontal ligament, and from other tooth structures. Periodontal ligament- } \\
\text { derived stem cells are able to generate periodontal ligament and cementum. } \\
\text { Extracted third molars, exfoliating/extracted deciduous teeth, and teeth extracted } \\
\text { for orthodontic treatment, trauma or periodontal disease are all sources of dental } \\
\text { stem cells from the dental pulp. The dental pulp offers a source of stem cells } \\
\text { postnatally that is readily available, with a minimally invasive process that results } \\
\text { in minimal trauma. Exfoliating or extracted deciduous teeth offer extra advantages } \\
\text { over other teeth as a source of stem cells. }\end{array}$ & 6 \\
\hline
\end{tabular}


Table III: Types of differentiation in stem cells

\begin{tabular}{|l|l|}
\hline Differentiation & Stem cell \\
\hline Direct differentiation & $\begin{array}{l}\text { A specific type of cell in a special niche developed in a multistep unidirectional pathway (e.g., } \\
\text { MSCs differentiating into osteoblasts/fibroblasts). }\end{array}$ \\
\hline Transdifferentiation & $\begin{array}{l}\text { Direct conversion of one cell type to another different cell type (e.g., blood cells into brain } \\
\text { cells and vice versa). }\end{array}$ \\
\hline Dedifferentiation & A unipotent stem cell becoming a multipotent one. \\
\hline Cell fusion & $\begin{array}{l}\text { A stem cell fusing with a somatic cell resulting in another lineage (e.g., ESCs fuse in vitro } \\
\text { with HSCs and neuronal cells). }\end{array}$ \\
\hline
\end{tabular}

Table IV: Cellular signals involved in cancer and their associated mechanism

\begin{tabular}{|c|c|c|}
\hline Signals & Associated mechanism & Reference \\
\hline Oct- 4 & $\begin{array}{l}\text { It is expressed only in the inner cell mass of the embryo, but not in the } \\
\text { trophectoderm, the structure that will form the extra-embryonic tissues. During } \\
\text { later development Oct- } 4 \text { expression is restricted to cells of the germ line and is } \\
\text { essential in maintaining totipotency and synchronous division. Loss of expression is } \\
\text { associated with differentiation of cells. } \\
\text { Oct- } 4 \text { is a marker for embryonal cancer and treatment with retinoids, which induce } \\
\text { differentiation of embryonal carcinomas, causes a decrease in expression of Oct- } 4 \text {. } \\
\text { It appears to be important in maintaining the undifferentiated state of embryonal } \\
\text { carcinoma as well as in other cancers. }\end{array}$ & 12 \\
\hline $\begin{array}{l}\text { Wnt/-catenin cell } \\
\text { activation pathway }\end{array}$ & $\begin{array}{l}\text { It is active in maintaining proliferation at an early stage of differentiation and } \\
\text { may have a similar role in cancer cells. Wnt signaling affects the orientation of the } \\
\text { chromosomes during mitotic division, and abnormalities in the orientation might } \\
\text { contribute to mitotic disjunctions typical of cancer cells. In general, Wnt/-catenin } \\
\text { signaling activates proliferation and inhibits apoptosis, the classic hallmarks of } \\
\text { cancer cells. }\end{array}$ & 12 \\
\hline Notch & $\begin{array}{l}\text { The Notch pathway plays a key role in the development and is increasingly } \\
\text { recognized for its importance in cancer. Notch pathways are expressed in } \\
\text { vasculature, alteration of Notch signaling in various endothelial cells generates } \\
\text { profound effects on angiogenesis in vitro. New evidence shows that Notch signaling } \\
\text { from tumor cells is able to activate endothelial cells and trigger tumor angiogenesis } \\
\text { in vitro and in a xenograft mouse tumor model. Selective interruption of Notch } \\
\text { signaling within tumors may provide an antiangiogenic strategy. }\end{array}$ & 13 \\
\hline BMP & $\begin{array}{l}\text { BMPs are members of the transforming growth factor- } \beta \text { (TGF- } \beta \text { ) superfamily } \\
\text { serving multiple functions in many cell and tissue types including proliferation, } \\
\text { apoptosis, differentiation, chemotaxis, angiogenesis, and matrix production during } \\
\text { embryogenic development as well as in adult life. Like TGF- } \beta \text {, an accepted "double- } \\
\text { edged sword" in tumor progression, BMPs may function both as oncogenes and } \\
\text { tumor suppressors depending on the relative dosage and disease stage. }\end{array}$ & 14 \\
\hline $\begin{array}{l}\text { Sonic hedgehog } \\
\text { signaling pathways }\end{array}$ & $\begin{array}{l}\text { The Hedgehog pathway is a major regulator of many fundamental processes } \\
\text { in vertebrate embryonic development including stem cell maintenance, cell } \\
\text { differentiation, tissue polarity and cell proliferation. This pathway has also } \\
\text { been shown to regulate proliferation of cancer stem cells and to increase tumor } \\
\text { invasiveness. }\end{array}$ & 15 \\
\hline
\end{tabular}


of the main problems in studying the role of stem cells in tumourigenesis has been the lack of stem-cell markers (16).

\section{Future perspective}

The introduction of the CSC concept has provided exciting insights into the roots of carcinogenesis and sheds light on the future cure of cancer. The impact from current and future studies of CSC will revolutionize clinical practice with regards to both cancer diagnosis and therapy. Two of the implicated changes will be the re-classification of human tumors and development of novel therapeutic strategies targeting CSC (17).

\section{CONCLUSION}

The discovery of CSCs in some tumor types has ushered in a new era of cancer research. CSC science is an emerging field that will ultimately impact researchers' understanding of cancer processes and may identify new therapeutic strategies. CSC's may present a challenge in the clinic. To achieve effective implementation of new therapies, physicians will require methods of determining the type (or types) of CSC's present in a given patient's tumor. It is important that agents directed against cancer stem cells discriminate between cancer stem cells and normal stem cells. However, much remains to be learned about these unique cells, which as of yet have not been identified in all tumor types. The characterization of CSCs will likely play a role in the development of novel targeted therapies designed to eradicate the most dangerous tumor cells, which may be resistant to current chemotherapy regimens, thereby providing researchers and clinicians with additional targets to alleviate the burden of cancer.

\section{REFERENCES}

1. Jensen KB, Jones J, Watt FM: A stem cell gene expression profile of human squamous cell carcinomas. Cancer Lett 2008, 272:23-31

2. Crowe DL, Parsa B, Sinha UK: Relationships between stem cells and cancer stem cells. Histol Histopathol 2004, 19:505-509

3. Beachy PA, Karhadkar SS, Berman DM: Tissue repair and stem cell renewal in carcinogenesis. Nature 2004, 432:324-331

4. Ariff B, Eng HL: Stem cell: from bench to bedside. 1st ed., Singapore, World Scientific Publishing, 2005, 1-10

5. Wagers AJ, Weissman IL: Plasticity of adult stem cells. Cell 2004, 116:639-648

6. Griffiths MJ, Bonnet D, Janes SM: Stem cells of the alveolar epithelium. Lancet 2005, 366:249-256

7. Andrew RM: Science in medicine: the JCI textbook of molecular medicine. 1st ed., United Kingdom, Jones and Bartlett Publishers, 2008, 819-821

8. Nadig RR: Stem cell therapy - Hype or hope? A review. J Conserv Dent 2009, 12:131-138

9. Fidler IJ: Cancer metastasis. Br Med Bull 1991, 47:157-177

10. Chen ZG: The cancer stem cell concept in progression of head and neck cancer. J Oncol 2009, 2009:894064

11. Li F, Tiede B, Massagué J, Kang Y: Beyond tumorigenesis: cancer stem cells in metastasis. Cell Research 2006, 1:1-12

12. Sell S: Stem cell origin of cancer and differentiation therapy. Crit Rev Oncol Hematol 2004, 51:1-28

13. Li JL, Harris AL: Notch signaling from tumor cells: a new mechanism of angiogenesis. Cancer Cell 2005, 8:1-3

14. Hsu MY, Rovinsky S, Penmatcha S, Herlyn M, Muirhead D: Bone morphogenetic proteins in melanoma: angel or devil? Cancer Metastasis Rev 2005, 24:251-263

15. Gupta S, Takebe N, LoRusso P: Review: Targeting the Hedgehog pathway in cancer. Therapeutic Advan Med Oncol 2010, 2: 237-250

16. Fürthauer M, González-Gaitán M: Endocytosis, asymmetric cell division, stem cells and cancer: unus pro omnibus, omnes pro uno. Mol Oncol 2009, 3:339-353

17. Guo W, Lasky JL, Wu H: Cancer Stem Cells. Ped Res 2006, 59: 59-65 